\title{
The Monkeys and Parrots of Gold Rush-era California
}

\author{
Cyler Conrad ${ }^{1,2^{*}}$ \\ ${ }^{1}$ Environmental Protection and Compliance, Los Alamos National Laboratory, Los Alamos, NM, USA \\ ${ }^{2}$ Department of Anthropology, University of New Mexico, Albuquerque, NM \\ *cylerc@lanl.gov; cyclerc@unm.edu
}

\begin{abstract}
As immigrant gold miners migrated en masse to San Francisco and northern California during the Gold Rush-era (ca. 1849-1855), they experienced new animals. Stopping in ports throughout Central and South America, these argonauts saw, felt, smelled, heard, and occasionally consumed, mammals, birds, reptiles, and many more creatures, which were wholly exotic to those species found at home. Two types of animals that the Gold Rush populace encountered during this era include parrots and monkeys. Although found throughout tropical environments in areas far distant from northern California, these animals became quickly imported to San Francisco during the early 1850s. A wild, turbulent Gold Rush-era helped facilitate the importation of these exotic animal types, both for comfort and entertainment, as they helped provide a source of companionship for miners unaccustomed to the shock of 1850 s northern California.
\end{abstract}

Received March 29, 2021

OPEN ӘACCESS

Accepted February 2, 2022

DOI 10.14237/ebl.13.1.2022.1758

Published March 8, 2022

Keywords San Francisco, Human-animal interaction, Parrot, Monkey, Exotic animal, Animal trade

Copyright (C) 2021 by the author(s); licensee Society of Ethnobiology. This is an open-access article distributed under the terms of the Creative Commons Attribution-NonCommercial 4.0 International Public License (https://creativecommons.org/licenses/by-nc/4.0), which permits non-commercial use, distribution, and reproduction in any medium, provided the original author and source are credited.

\section{Introduction}

Animals experienced all of the trials and tribulations of California's Gold Rush. Whether it was local wild game, domesticates, or exotic imported species, the exploitative nature of San Francisco's human populace between 1849 and 1860 created enormous demand for animals, their products, curiosities, and entertainment. Primarily, this demand focused on animals for food-a pattern supported by archaeological evidence from the Gold Rush-era (Conrad et al. 2015a) - but animals also filled several other social niches. Domesticated cattle (Bos taurus), pigs (Sus scrofa) and sheep (Ovis aries) were dietary staples (Soulé et al. 1854). Cats (Felis catus) and dogs (Canis familiaris) were kept as pets and provided a means to eradicate rats (Rattus sp.). Rats provided a convenient source of societal-wide empathy; everyone suffered from rats, everyone tried to kill rats. Local oysters (Ostrea lurida) reminded immigrants from the eastern United States of home, albeit not nearly as delectable as those found from home itself (i.e., Crassostrea virginica; Booker 2006). Hunting elk (Cervus canadensis), deer (Odocoilens hemionus), birds, fish, and all other wild creatures provided economy through the wild game market for those immigrants who failed to find riches in the gold fields (Stine 1980). Galapagos tortoises (Chelonoidis sp.) and sea turtles (e.g., Chelonia mydas) provided a source of dietary relief and survival from poor-quality foods kept and served on vessels traveling long-distances to reach San Francisco, and these same animals were also kept by miners as pets, food, and entertainment (Conrad and Pastron 2014; Conrad et al. 2018). For more entrepreneurial spirits, Australian imported kangaroos (Macropodidiae) provided entertainment, and likely the occasional bite to eat (Conrad 2017). Thousands of people who migrated to San Francisco and northern California during this era clearly experienced animals in new ways, whether through food or otherwise, just as these animals experienced humans, and environments, in very new and shocking ways. One of these novel Gold Rush-era experiences involves humans and the animals they imported from Central America and South America: parrots and monkeys.

\section{A Gold Rush Menagerie}

The bustling, tumultuous residents of early 1850s San Francisco were undoubtedly shocked by the arrival of 
fifty parrots and five monkeys on the brigantine Democrazia, 50 days direct from El Realejo, Nicaragua, on March 15, 1853 (Anon 1853c). Understood in context of the city's dreary, wet, disorganized, and hectic conditions during the Gold Rush, the vibrant colors and loud vocalizations of parrots would likely have drawn awe-struck crowds to the wharf. Nicaragua has four parrot species that may have been imported, including the scarlet macaw (Ara macao), and all of these species have bright, colorful plumage. During this same arrival, one of three Nicaraguan primate (i.e., monkey) species arrived (or perhaps individuals from several species), including either the mantled howler (Alouatta palliata), white-faced capuchin (Cebus imitator), or Geoffroy's spider monkey (Ateles geoffroyı). It is not difficult to imagine that once landed in San Francisco these monkeys likely inspired fascination to the Gold Rush populace.

Although it is possible that portions of the immigrant Gold Rush population were familiar with these animals through travel across Central America or South America en route to San Francisco (Delgado 1996), for most prospective miners they were animals of fascination, perhaps only understood through stories, drawings, or circuses from home. A large portion of immigrant miners arrived from the eastern United States, and this era was approximately two decades prior to the establishment of what we know today as formal zoos during the 1870s. Therefore, to a large portion of the human population, parrots and monkeys represented unknown, rare, exotic species from far-away places, and yet they were now in San Francisco. Certainly, this importation was for amusement and menagerie. Their representation in historical records supports this interpretation-and suggests that parrots and monkeys likely arrived before and after the Democrazia landed in Gold Rushera San Francisco.

For example, after a fire that swept through San Francisco on June 22, 1851, an advertisement placed in the Daily Alta California requested help finding a lost "black Brazilian monkey" (Anon 1851b). It is unclear if this monkey was the same owned by a French immigrant named Jean Allesore, "who is usually seen with a hand-organ and a monkey," in San Francisco (Anon 1851d). Or take the April 17, 1851, fair at Lee's Exchange in Sacramento, California, where monkeys were displayed and it was noted that, "[h] takes a good look at the monkey, and departs, satisfied that he has got his money's worth" (Anon 1851a). At least one hand-organ, red-jacketed monkey appears to be commonly referenced in San Francisco during the Gold Rush (Anon 1852b, see 1852c and $1854 \mathrm{~g}$ in Conrad 2021). One traveler reminisced (Anon 1850b):

I happened to be seated, at the time, in the bar-room of one of the hotels, in conversation with a friend, when the sounds of an instrument associated with so many familiar recollections fell like the strains of some long forgotten, but cherished voice upon my ears. I rushed out to behold the adventurous Savoyard who had traversed half the globe to charm the savage natures of this wild and lawless region with the dulcet tones of his instrument...The dear little automatons, that had excited my wonder and admiration as a child, were pirouetting, as of old, upon the instrument, and the attendant monkey clambering from post to pillar, grinning his at the numberless presents of fruit or biscuit that he received...The melodious strains of his instrument never failed to arouse the enthusiasm of the homesick, whilst the tricks of the monkey served to amuse the leisure of the rough miners who were incapable of entering into the feelings inspired by his music.

During the Gold Rush era, monkeys appear continuously referenced as a form of pet or entertainment. One individual sued another when her pet monkey and fox were reportedly stolen in San Joaquin, California (Anon 1852e). An advertisement for local "amusements" in San Francisco indicated the presence of the "National Circus," including "Jack Robinson and his Monkey!" (Anon 1852f). A second monkey was lost in June 1852 from the "Hotel Francaise" with a request for return and reward in local papers (Anon 1852g). By 1854, a "Professor" traveled through northern California with his "excruciating music of his harmonic establishment, and the vagaries of his monkey" (Anon 1854a, see 1854e and 1854f in Conrad 2021). By late 1854, northern California newspapers described an individual "parading about leading a horse attached to 
a soda wagon, a diminutive monkey being perched on the back of the animal" (Anon 1854h). Imported primates clearly held a role in the social fabric of California's Gold Rush.

Parrots also appear in Gold Rush-era historic records, but often in the context of pets lost or stolen. These birds were treasured and valued. Numerous advertisements published between 1850-1854 request help and offer rewards for lost parrots. Descriptions include, "a Parrot, with a red breast, wing and tail clipped," a "blueish grey parrot with a red tipped tail," a "beautiful green parrot with a red head," a "small bird, green color, with blue and yellow feathers on the head, her wings tipped with red," a "King Parrot, lead color, with pink breast," and "[a] large Parrot or Macaw, with red and yellow feathers," among several others (see Anon 1850a, 1850c, 1851c, 1852a, 1852h, 1852i, 1853b, 1853d, 1854b, 1854c, 1854d in Conrad 2021). In one case, the return of a "King Parrot" lost on November 3, 1852, was offered a $\$ 20$ reward - ten days later this reward increased to $\$ 50$ (see Anon 1852 $\mathrm{j}$ and 1852k in Conrad 2021).

Later $19^{\text {th }}$ century zooarchaeological-based records from San Francisco also support the presence of exotic parrots in northern California. In one example, excavation of a privy context dating to the 1870s included the recovery of bones belonging to a lilac-crowned parrot (Amazona finschi), likely kept as a

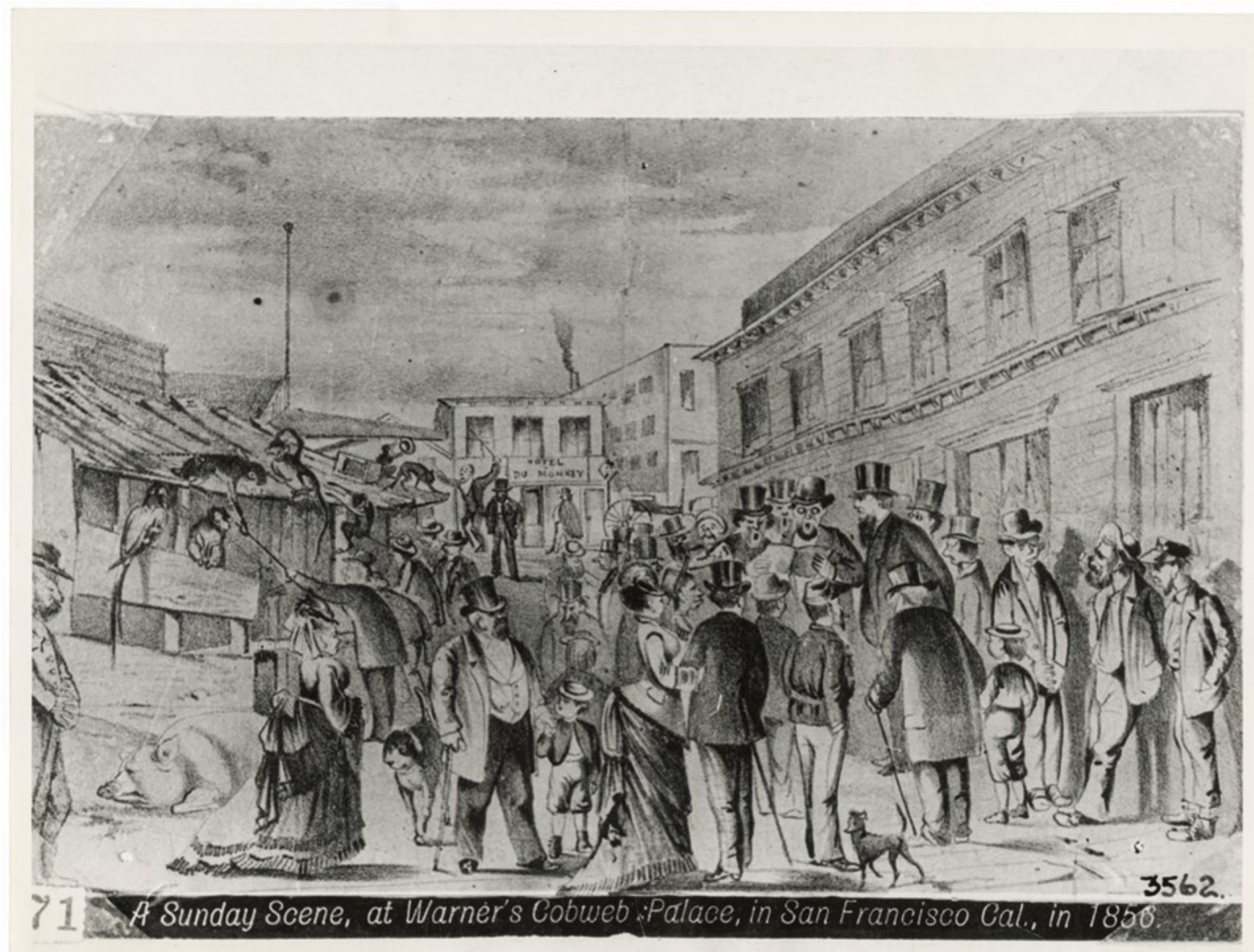

Figure 11856 drawing of the "Cobweb Palace" in San Francisco. Image courtesy of Lauren Menzies and The Society for California Pioneers. 
pet (Praetzellis and Praetzellis 2009). A second context dating to the 1870 s-1880s also included the bones of a blue cheeked amazon (Amazona dufresniana), again, likely kept as a pet (William Self Associates, Inc. 2019). Parrots provided a source of companionship during this time.

\section{Discussion}

While written records and archaeological samples enable a reconstruction of the relationship between humans, parrots and monkeys in Gold Rush-era California, a drawing published in 1856 showing the "Cobweb Palace" in San Francisco helps visualize these experiences (Figure 1). The Cobweb Palace was constructed in 1855 and was described as, "famous in its way as the old curiosity-shop of Charles Dickens," (Anon 1892) suggesting that it is a location where one might expect to find exotic animals during this period. As the drawing depicts, a large crowd of individuals stand outside the establishment in the street along with two dogs, a large pig, a single, elegant-looking parrot-possibly a scarlet macaw based on the tail feather morphology-and six monkeys, which appear to be both indifferent, and equally terrorizing, to the crowd. Individuals appear captivated by the monkeys and annoyed with their antics.

For the parrots and monkeys imported from Central and South America, or perhaps elsewhere (the "King Parrot" may be an Australian king parrot

Table 1 A non-exhaustive list of animals imported into San Francisco and northern California during the Gold Rush era (see Conrad 2021 for supplemental references). This list primarily focuses on wild-caught animals (e.g., not cattle, sheep/goats, pigs, horses, chickens, and others). Numerous types of fish and other seafood were also imported during this period and are not included here (see Conrad et al. 2021 for details). "?" indicates possible reason for use based on the historic record.

\begin{tabular}{|c|c|c|c|c|}
\hline Animal & Origin & Use & Current Basis for Record & Reference \\
\hline Galapagos tortoise & Galapagos Islands & Subsistence & Archaeological/Historical & $\begin{array}{l}\text { Conrad and Pastron 2014; } \\
\text { Conrad and Gibbs 2020; } \\
\text { Conrad et al. 2015a }\end{array}$ \\
\hline Sea turtles & Eastern Pacific Ocean & $\begin{array}{l}\text { Subsistence, } \\
\text { Entertainment? }\end{array}$ & Archaeological/Historical & $\begin{array}{l}\text { Conrad and Pastron 2014; } \\
\text { Conrad et al. 2018; } \\
\text { Conrad et al. } 2015 a\end{array}$ \\
\hline Oysters & $\begin{array}{l}\text { Pacific Northwest and } \\
\text { the Eastern United } \\
\text { States (Atlantic Ocean) }\end{array}$ & Subsistence & Archaeological/Historical & $\begin{array}{l}\text { Booker 2006; Conrad et al. } \\
\text { 2015b }\end{array}$ \\
\hline Kangaroos & Australia & $\begin{array}{l}\text { Entertainment, } \\
\text { Subsistence? }\end{array}$ & Historical & Conrad 2017 \\
\hline Atlantic cod & Atlantic Ocean & Subsistence & Archaeological/Historical & Conrad et al. 2021 \\
\hline Parrots & $\begin{array}{l}\text { Central/South America/ } \\
\text { Australia }\end{array}$ & $\begin{array}{l}\text { Entertainment, } \\
\text { Pet }\end{array}$ & Archaeological/Historical & This study \\
\hline Monkeys & Central/South America & $\begin{array}{l}\text { Entertainment, } \\
\text { Pet }\end{array}$ & Historical & This study \\
\hline Seashells & $\begin{array}{l}\text { Pacific Ocean (and pos- } \\
\text { sibly elsewhere) }\end{array}$ & Keepsake, Gift? & Archaeological/Historical & Conrad et al. 2015a \\
\hline Grizzly bear & Oregon & Unknown & Historical & $\begin{array}{l}\text { Anon } 1852 d \text { (see also Ken- } \\
\text { nedy et al. } 2018 \text { ) }\end{array}$ \\
\hline "tame" deer & Central America & Unknown & Historical & Anon $1853 a$ \\
\hline Canary birds & East Asia (Hong Kong) & Unknown & Historical & Anon $1853 a$ \\
\hline Swedish leeches & $\begin{array}{l}\text { Sweden (and else- } \\
\text { where in Europe) }\end{array}$ & Medicinal & Historical & Anon 1856 \\
\hline
\end{tabular}


[Alisterus scapularis]), arrival in San Francisco during the Gold Rush era was likely shocking and undesired, but for their human captors this translocation was an exciting necessity. Whether captive as pets, or for economic prosperity, Gold Rush immigrants exploited these animals and relied on their interaction. Historic and archaeological records support this type of human-animal relationship during the 1850s in northern California, given evidence supporting the importation and exploitation of a variety of nonnative species for food or otherwise. In many ways, the long-distance voyages required to arrive in San Francisco and the gold fields, the unfamiliar food, sights, smells, and weather, the lack of family, and the lack of an established social network, suggest that the Gold Rush populace relied on animals_-regardless of type-for their bond and companionship (e.g., Spencer et al. 2006). Animals filled a void created by the often-overwhelming experience of the Gold Rush era, and it was the exoticness of this time that enabled the exoticization of these human-animal interactions.

Evidence from the eastern United States also supports this record. For example, zooarchaeological analysis of bird skeletal remains from a privy at the Heyward-Washington House in Charleston, South Carolina, confirmed the presence of a blue-fronted or turquoise-fronted amazon parrot (Amazona aestiva) dating to the early $19^{\text {th }}$ century (Zierden et al. 2019). Charleston, like San Francisco during and after the Gold Rush (Delgado 2009), was a seaport city and global center of commerce. International connections established by trade and mercantile activities brought

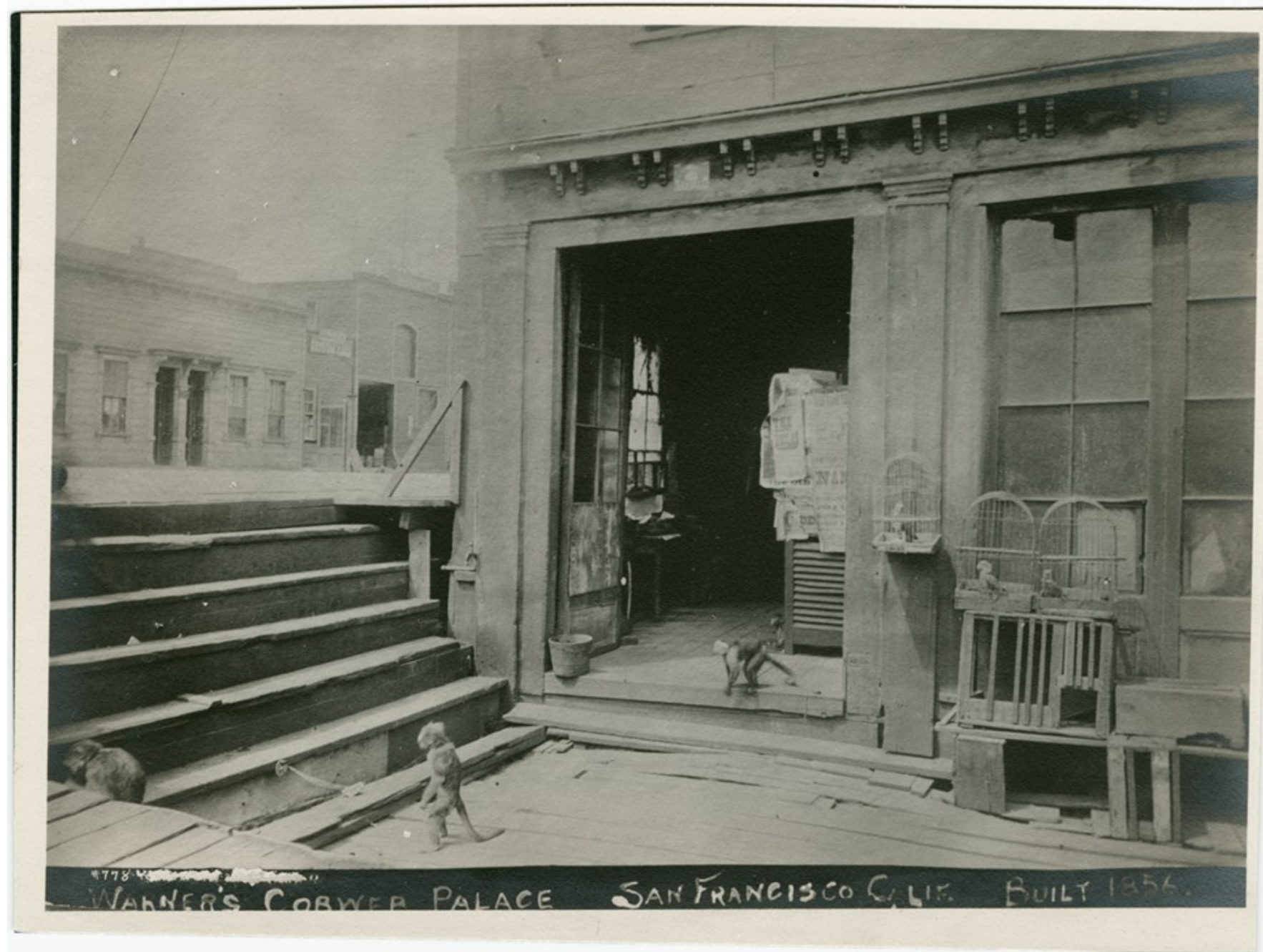

Figure 2 A late- $19^{\text {th }}$ or early- $20^{\text {th }}$ century photograph of the "Cobweb Palace" in San Francisco. Courtesy of Christina Moretta and the San Francisco History Center, San Francisco Public Library. 
exotic goods to these locations, and exotic animals quickly became entangled with this trade (see Grier 2006). Animals, pets or otherwise, were viewed as prestige items and commodities within these contexts.

It is thus not surprising that Gold Rush immigrants managed to import such non-native and unfamiliar animals into northern California (Table 1). And, while the modern 'wild' parrots of San Francisco (Bittner 2007) almost certainly do not relate in any way to these imported Gold Rush birds, the long-term record of exotic animals present in northern California speaks to the social structure created by, and evolved from, these human-animal relationships established during the Gold Rush era (Figure 2). Later 19th century importation of bear paws from southwestern Canada into the San Francisco Bay area is an excellent example of the long-term continuation of these processes (Kennedy et al. 2018).

Monkeys and parrots now join kangaroos, Galapagos tortoises, sea turtles, oysters, and likely several other animals that lived, witnessed, and experienced this significant time in California's history.

\section{Acknowledgments}

Thank you to Kale Bruner and Allen Pastron for making this research possible. I am also grateful to archival support provided by Martha Zierden, Lauren Menzies and The Society for California Pioneers, and Christina Moretta and the San Francisco History Center, San Francisco Public Library. As always, thank you to the California Digital Newspaper Collection managed by the Center for Bibliographic Studies and Research, University of California, Riverside, for facilitating access to archival newspaper collections. Thank you to two anonymous reviewers and Maria Bruno for providing invaluable feedback on earlier drafts of this manuscript.

\section{Declarations}

Permissions: None declared.

Sources of funding: None declared.

Conflicts of Interest: None declared.

\section{References Cited}

Bittner, M. 2007. The Wild Parrots of Telegraph Hill. Three Rivers Press, New York, NY.

Booker, M. M. 2006. Oyster Growers and Oyster Pirates in San Francisco Bay. Pacific Historical Review 75(1):63-88. DOI:10.1525/phr.2006.75.1.63.
Conrad, C. 2017. Kangaroos and the California Gold Rush. California History 94(3):62-65. DOI:10.1525/ ch.2017.94.3.62.

Conrad, C. 2021. Compendium for the paper The Monkeys and Parrots of Gold Rush-era California. DOI:10.17605/OSF.IO/6Y7Q8.

Conrad, C., and A. Pastron. 2014. Galapagos Tortoises and Sea Turtles in Gold Rush-Era California. California History 91(2):20-39. DOI:10.1525/ch.2014.91.2.20.

Conrad, C., K. W. Gobalet, K. Bruner, and A. G. Pastron. 2015a. Hide, Tallow and Terrapin: Gold Rush-Era Zooarchaeology at Thompson's Cove (CA-SFR-186H), San Francisco, California. International Journal of Historical Archaeology 19:502551. DOI:10.1007/s10761-015-0297-2.

Conrad, C., L. Pagès Barceló, J. A. Seminoff, C. Turner Tomaszewicz, M. Labonte, B. M. Kemp, E. L. Jones, M. Stoyka, K. Bruner, and A. Pastron. 2018. Ancient DNA Analysis and Stable Isotope Ecology of Sea Turtles (Cheloniidae) from the Gold Rush-era (1850s) Eastern Pacific Ocean. Open Quaternary 4(1). DOI:10.5334/oq.41.

Daily Alta California. 1851b. Lost. Published on June 26, 1851.

Daily Alta California. 1851d. Recorder's Court. Published on December 30, 1851.

Daily Alta California. 1852b. March of civilization. Published on January 26, 1852.

Daily Alta California. 1852f. Amusements. Published on June 13, 1852.

Daily Alta California. 1852g. Lost. Published on June 18, 1852.

Daily Alta California. 1853c. Importations. Published on March 15, 1853.

Delgado, J. 1996. To California by Sea: A Maritime History of the California Gold Rush. University of South Carolina Press, Columbia, SC.

Delgado, J. 2009. Gold Rush Port: The Maritime Archaeology of San Francisco's Waterfront. University of California Press, Berkeley, CA.

Grier, K. C. 2006. Pets in America: A History. The University of North Carolina Press, Chapel Hill, NC.

Kennedy, J. R., L. Rogers, and F. A. Kaestle. 2018. Ancient DNA Evidence for the Regional Trade of Bear Paws by Chinese Diaspora Communities in 
19th-Century Western North America. Journal of Archaeological Science 99:135-142. DOI:10.1016/ j.jas.2018.09.005

Marysville Daily Herald. 1850b. Adventures in California. Published on September 13, 1850.

Praetzellis, M., and A. Praetzellis. 2009. South of Market: Historical Archaeology of 3 San Francisco Neighborhoods. Archaeological Studies Center, Rohnert Park, CA.

Sacramento Daily Union. 1854a. Musical. Published on January 30, 1854.

Sacramento Daily Union. 1854h. Street Scenes. Published on December 1, 1854.

Sacramento Transcript. 1851a. The Fair. Published on April 18, 1851.

San Francisco Call. 1892. The Cobweb Palace. Published on December 1, 1892.

San Joaquin Republican. 1852e. The Monkey and the Fox. Published on April 14, 1852.

Spencer, S., E. Decuypere, S. Aerts, and J. De Tavernier. 2006. History and Ethics of Keeping
Pets: Comparison with Farm Animals. Journal of Agricultural and Environmental Ethics 19:17-25. DOI:10.1007/s10806-005-4379-8

Soulé, F., J. H. Gihon, and J. Nisbet. 1854. Annals of San Francisco. Appleton, New York, NY.

Stine, S. W. 1980. Hunting and the Faunal Landscape Subsistence and Commercial Venery in Early California. Unpublished Master's Thesis, Department of Geography, University of California, Berkeley.

William Self Associates, Inc. 2019. Transbay Program, Final Archaeological Resources Report, Addressing Block 9 of the Transbay Redevelopment Project Area. William Self Associates, Inc., Orinda, CA.

Zierden, M. A., E. J. Reitz, B. Pavao-Zuckerman, L. J. Reitsema, and B. L. Manzano. 2019. What Is This Bird? The Quest to Identify Parrot Remains from the Heyward-Washington House, Charleston, South Carolina. Southeastern Archaeology 38(3):240-255. DOI:10.1080/0734578X.2018.1555407 